\title{
Unusual cause for overt upper gastrointestinal bleeding
}

\author{
Jacob Hatt, Sarah Mills
}

Northumbria Healthcare NHS Foundation Trust, North Shields, UK

\section{Correspondence to} Jacob Hatt,

jrhatt86@gmail.com

Accepted 19 February 2016

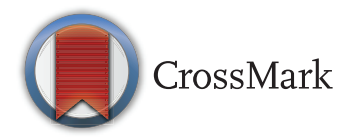

To cite: Hatt J, Mills S. BMJ Case Rep Published online: [please include Day Month Year] doi:10.1136/bcr-2016214846

\section{DESCRIPTION}

A 66-year-old woman with a history of aortic stenosis, ischaemic heart disease, chronic obstructive pulmonary disease and hypertension presented to accident and emergency department, with sudden onset haematemesis and melaena. Haemoglobin on arrival was $49 \mathrm{~g} / \mathrm{L}$. Following immediate resuscitation, she underwent upper gastrointestinal endoscopy. After futile attempts to control the bleeding, the procedure was abandoned due to what the endoscopist described as 'profuse bleeding from D2'. Following discussion with the patient, an emergency laparotomy was performed.

At operation, blood was evident throughout the gastrointestinal tract. Duodenotomy was performed, which revealed bile in D1 but no active bleeding nor ulceration. The duodenum was kocherised in order to further explore the possibility of a hepatopancreatobiliary source, but no obvious pathology was found.

The entirety of the bowel was examined, with no obvious abnormality initially identified. At this point, blood was noted from the efferent limb of the duodenotomy. The D-J flexure was mobilised

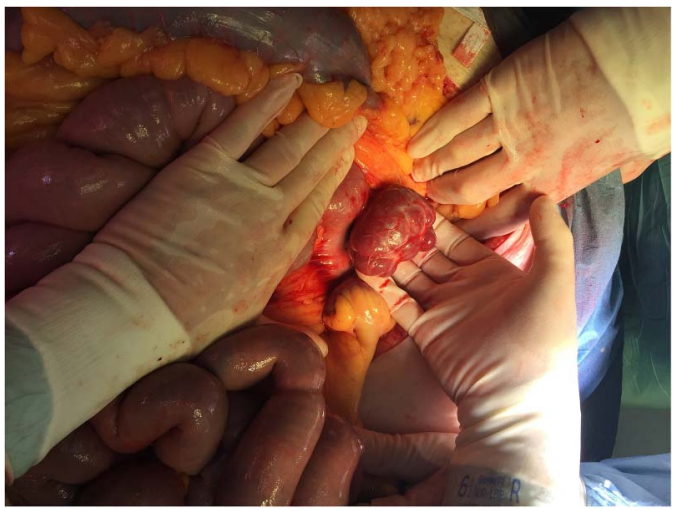

Figure 1 Posterior small bowel diverticulum found at laparotomy. from the retroperitoneum, revealing a large posterior diverticulum full of clot (figure 1). The diverticulum was simply excised with a single fire from a linear stapler cutter, all clot evacuated and a noncrushing clamp applied distal to the presumed site of bleeding. After a haemostatic pause, no further bleeding was identified. The duodenotomy was closed and the patient went on to make a full recovery. Histology confirmed a $40 \times 27 \times 17 \mathrm{~mm}$ small bowel diverticulum with evidence neither of dysplasia nor of malignancy.

\section{Learning points}

- Small bowel diverticula are far less common than colonic diverticula, with the true incidence unknown due to the vast majority of patients being asymptomatic. ${ }^{1}$

- A small bowel diverticular bleed should be considered in patients with overt upper gastrointestinal tract bleeding in which no clear source can be identified on upper gastrointestinal endoscopy.

- With a portion of the small bowel being retroperitoneal, full mobilisation of the bowel may be required in order to locate the source of bleeding.

Contributors SM and JH performed the surgery and contributed to subsequent clinical care of the patient. JH reviewed the literature and wrote the case report. SM reviewed and edited the case report.

Competing interests None declared.

Patient consent Obtained.

Provenance and peer review Not commissioned; externally pee reviewed.

\section{REFERENCE}

1 Gunjan D, Sharma V, Rana SS, et al. Small bowel bleeding: a comprehensive review. Gastroenterol Rep (Oxf) 2014;2:262-75.

Copyright 2016 BMJ Publishing Group. All rights reserved. For permission to reuse any of this content visit http://group.bmj.com/group/rights-licensing/permissions.

BMJ Case Report Fellows may re-use this article for personal use and teaching without any further permission.

Become a Fellow of BMJ Case Reports today and you can:

- Submit as many cases as you like

- Enjoy fast sympathetic peer review and rapid publication of accepted articles

- Access all the published articles

- Re-use any of the published material for personal use and teaching without further permission

For information on Institutional Fellowships contact consortiasales@bmjgroup.com

Visit casereports.bmj.com for more articles like this and to become a Fellow 